\title{
Genetic diversity of cassava landraces cultivated in northern Mato Grosso State, Brazil, using microsatellite markers
}

\author{
E.C.M. Pedri ${ }^{1,2,3}$, E.S.S. Hoogerheide ${ }^{4}$, A.V. Tiago ${ }^{1,3}$, E.S. Cardoso ${ }^{1,3}$, \\ J.M.A. Pinto ${ }^{4}$, L.L. Santos ${ }^{1}$, O.M. Yamashita ${ }^{1}$ and A.A.B. Rossi ${ }^{1,2,3}$ \\ ${ }^{1}$ Universidade do Estado de Mato Grosso Carlos Alberto Reyes Maldonado, \\ Faculdade de Ciências Biológicas e Agrárias, Centro de Pesquisa e \\ Tecnologia da Amazônia Meridional, Laboratório de Genética Vegetal e \\ Biologia Molecular, Campus de Alta Floresta, MT, Brasil \\ ${ }^{2}$ Programa de Pós-Graduação em Biodiversidade e Agroecossistemas \\ Amazônicos, Alta Floresta, MT, Brasil \\ ${ }^{3}$ Programa de Pós-Graduação em Biodiversidade e Biotecnologia da Rede \\ Bionorte/UNEMAT, Alta Floresta, MT, Brasil \\ ${ }^{4}$ Embrapa Agrossilvipastoril, Sinop, MT, Brasil \\ Corresponding author: E.C.M. Pedri \\ E-mail: elicmbio@gmail.com
}

Genet. Mol. Res. 18 (3): gmr18315

Received April 03, 2018

Accepted June 28, 2019

Published July 04, 2019

DOI http://dx.doi.org/10.4238/gmr18315

\begin{abstract}
Cassava (Manihot esculenta) is a traditional crop in tropical and subtropical regions that is used for human consumption and in animal feed. This studied cassava landraces cultivated in northern Mato Grosso State, Brazil, to detect the variability in family farms, aiming at the preservation and use potential of these genetic resources. A total of $120 \mathrm{M}$. esculenta individuals were evaluated at the rate of 40 per location (population), where each landrace was represented by 10 plants. The 14 microsatellite markers examined showed genetic diversity. The average polymorphic information content (PIC) was 0.621 and the average number of alleles per locus was seven. Genetic diversity parameters indicated that $H_{o}$ was higher than $H_{e}$ for the three populations, showing negative fixation indices and a lack of inbreeding. AMOVA revealed greater molecular variation within the populations $(92 \%)$. Bayesian analysis and the
\end{abstract}


UPGMA clustering method resulted in two main groups formed with the individuals distributed randomly; i.e., regardless of collection site (location). The gene flow found in this study is a consequence of the introduction and exchange of genetic material (landraces) performed by the farmers, who act on their farms as maintainers of local diversity. Manihot esculenta cultivation in northern Mato Grosso State ensure the on-farm conservation of genetic variability of the species and constitutes a source of genetic resources such as genes of resistance and adaptation, which can be exploited and utilized in breeding programs.

Key words: Manihot esculenta; SSR; Genetic Variability

\section{INTRODUCTION}

Originating from South America (Allem, 2002), the cassava (Manihot esculenta, Euphorbiaceae) is the only species of the genus that is cultivated for commercial purposes. This native Brazilian plant is grown across almost the entirety of the country's territory (Flora do Brasil, 2020). Its genetic variability allows it to adapt to different edaphoclimatic conditions (Moura et al., 2013).

According to the Brazilian Institute of Geography and Statistics (IBGE), in January 2019, the Brazilian cassava root production was 14.9 million tons, which was grown in an area of 1.4 million hectares (CONAB, 2019). In a regional context, in 2017, the state of Mato Grosso produced 277,007 tons in a harvested area of 19,093 hectares, with an average yield of 14,508 kg.ha ${ }^{-1}$ (IBGE, 2019). In the central-west region of the country, cassava is grown mainly on family farms due to its easy propagation, adaptation to different soilclimatic conditions and productive potential. The produce is targeted towards own consumption, animal feeding and agro-industries (Marchetti et al., 2013; Moura et al., 2013; Tumuhimbise et al., 2014).

The genetic variability of cassava in Brazil is maintained in work collections and germplasm banks, where it is represented mainly by native varieties and/or those selected by farmers (Ribeiro et al., 2011). Another alternative is on-farm conservation, which is performed on small farms where the producers select cassava landraces according to their needs. Their interest does not lie in genetic value, but rather in yield and ease of management (Oler et al., 2017). The role played by farmers, such as, in the case of cassava, introduction and exchange of plant material, ensures the conservation of genetic resources, thereby acting as maintainers of local diversity (Elias et al., 2004; Martins and Oliveira, 2009; Santonieri et al., 2016; Tiago et al., 2016).

The cassava landraces cultivated on family farms constitute a genetic resource that should be preserved and may be used in breeding programs by virtue of their resistance genes and easy adaptation (Faraldo et al., 2000; Fukuda et al., 2005).

At present, different methods are used in the characterization of genetic resources; e.g. morphological, agronomic, and molecular characterization. Because inter- and intraspecific variability is detected in molecular characterization via markers (Souza, 2015; Pereira et al., 2016), it is an effective method in the study of genomes, as polymorphism can be identified directly at the DNA level without environmental influences (Ferreira and 
Grattapaglia, 1998). Among the markers based on PCR amplification are microsatellites, also known as SSR (Simple Sequence Repeat) markers.

SSRs are abundant and uniformly distributed across the genome. They involve a small amount of DNA and have a high level of polymorphism, codominant inheritance and a multiallelic nature (Guimarães et al., 2009; Siqueira et al., 2010). For these reasons, SSRs have been widely employed and have yielded satisfactory results in the evaluation of genetic diversity and population structure of M. esculenta (Turyagyenda et al., 2012; Beovides et al., 2015; Moura et al., 2016; Gonçalves et al., 2017). Along this line, we studied cassava landraces cultivated in northern Mato Grosso State, Brazil, to detect the existing variability on family farms, aiming at the conservation and use potential of these genetic resources.

\section{MATERIAL AND METHODS}

\section{Study area}

This study involved three municipalities (Alta Floresta (AF), Terra Nova do Norte (TN) and Apiacás (AP)) of northern Mato Grosso State, Brazil (Figure 1). The climate of the municipalities is an Am type with rainy and dry seasons, average annual temperatures $>26^{\circ} \mathrm{C}$ and precipitation ranging from 2800 to $3100 \mathrm{~mm}$ (Alvares et al., 2013).

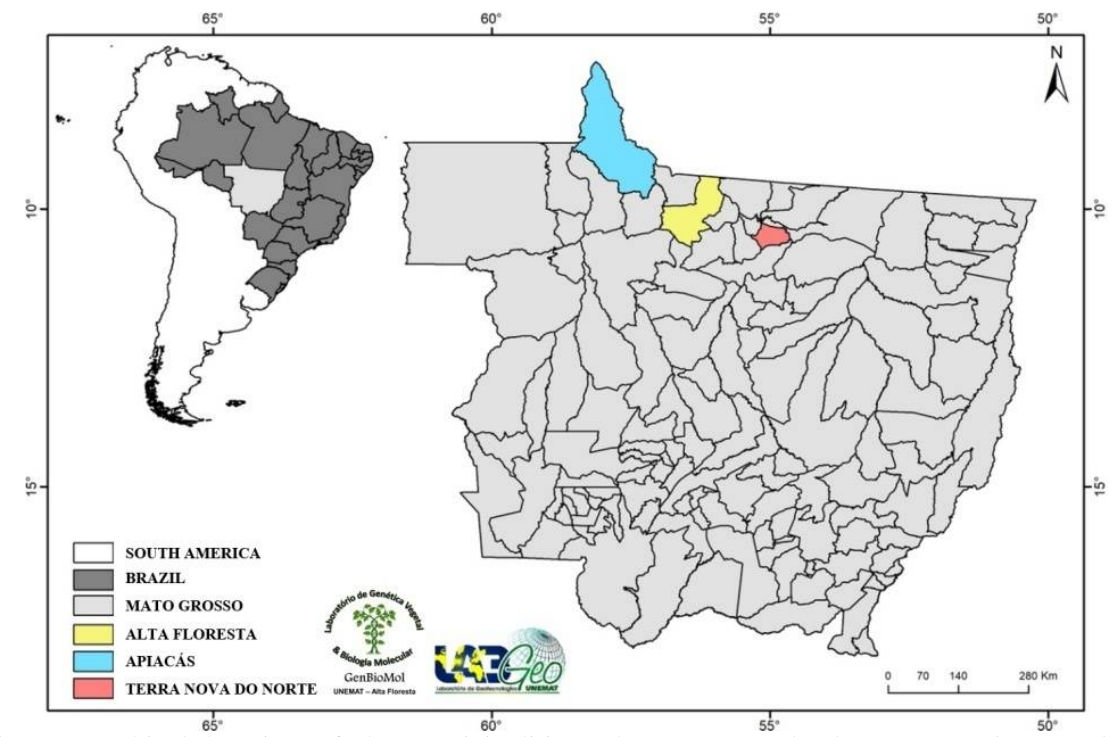

Figure 1. Geographical location of the municipalities where cassava landraces (Manihot esculenta) were collected in northern Mato Grosso, Brazil.

\section{Plant material}

Leaf samples were collected from 10 plants. Two plants of each of the four landraces were collected per farm. Thus, 40 plants were sampled per municipality, totaling 120 M. esculenta individuals (Table 1). 
Table 1. Discrimination of the cassava landraces collected in three municipalities in northern Mato Grosso state. Five farms were visited per municipality for each landrace and 10 plants were sampled per municipality for each landrace.

\begin{tabular}{lll}
\hline Landraces & Code & Municipality \\
\hline Cacau branca & CB & Alta Floresta \\
Cacau roxa & CR & Alta Floresta \\
Cacau amarela & CA & Alta Floresta \\
Mandioca pão & MP & Alta Floresta \\
Cacau branca & CB & Terra Nova do Norte \\
Cacau roxa & CR & Terra Nova do Norte \\
Cacau amarela & CA & Terra Nova do Norte \\
Mandioca pão & MP & Terra Nova do Norte \\
Cacau branca & CB & Apiacás \\
Cacau roxa & CR & Apiacás \\
Cacau amarela & CA & Apiacás \\
Mandioca pão & MP & Apiacás \\
\hline
\end{tabular}

The young leaves were immediately placed in polypropylene tubes $(2 \mathrm{~mL})$ containing $1 \mathrm{~mL}$ saturated $\mathrm{NaCl}-\mathrm{CTAB}$ solution (transport buffer $=70 \mathrm{~g} \mathrm{NaCl}$ and $3 \mathrm{~g}$ CTAB dissolved in $200 \mathrm{~mL}$ autoclaved distilled water). Subsequently, they were stored in a refrigerator at $4^{\circ} \mathrm{C}$.

\section{DNA extraction and quantitation}

Approximately $100 \mathrm{mg}$ of leaves were washed in tap water to remove excess buffer. The material was macerated in a mortar and pestle containing $1.5 \mathrm{~mL}$ STE buffer $(130 \mathrm{~g}$ sucrose, $4.5 \mathrm{~mL} 1 \mathrm{M}$ Tris $\mathrm{HCl}, 15 \mathrm{~mL}$ 0.5M EDTA, completing the volume to $1500 \mathrm{~mL}$ with autoclaved distilled water).

The total DNA extraction followed the CTAB protocol (cetyltrimethylammonium bromide) described by Doyle and Doyle (1987) with modifications: $1 \%$ polyvinylpyrrolidone (PVP), 3\% CTAB and 2\% $\beta$-mercaptoethanol in the extraction buffer.

Quantification was achieved using a spectrophotometer (Nanodrop-2000 Thermo Scientific). To evaluate concentration and purity, the DNA was stained with GelRed after electrophoresis on $1 \%$ agarose gel. The gel was visualized and photographed using a L-PIX Image transilluminator (Loccus Biotechnology).

\section{Microsatellite amplification}

Fourteen loci developed by Chavarriaga-Aguirre et al. (1998) and Mba et al. (2001) were used in this study (Table 2).

Amplification via PCR was performed with addition of the M13 tail using the methodology described by de Schuelke (2000). The reactions were standardized with a final volume of $10 \mu \mathrm{L}$ containing $20 \mathrm{ng} \mu \mathrm{L}-1$ DNA; 1 U TAQ-Polymerase; $10 \mathrm{mM}$ Tris-HCL; $\mathrm{pH} 8.3 ; 50 \mathrm{mM} \mathrm{KCL} ; 0.2 \mathrm{mM}$ dNTP; 0.026 and $0.05 \mu \mathrm{M}$ of each primer (forward and reverse, respectively); and $0.05 \mu \mathrm{MHEX}$ or FAM (fluorescent dyes), and the volume was completed with Milli- $\mathrm{Q}^{\circledR}$ ultrapure $\mathrm{H}_{2} \mathrm{O}$.

Amplification reactions were conducted in a T100 "Thermal Cycler" (BIO-RAD) thermocycler with one initial denaturation cycle at $94^{\circ} \mathrm{C}$ for $5 \mathrm{~min}$, followed by 30 cycles at 
$94^{\circ} \mathrm{C}$ for $30 \mathrm{~s}, 45^{\circ} \mathrm{C}$ for $45 \mathrm{~s}$ and $72^{\circ} \mathrm{C}$ for $45 \mathrm{~s}, 8$ cycles at $94^{\circ} \mathrm{C}$ for $30 \mathrm{~s}, 53^{\circ} \mathrm{C}$ for $45 \mathrm{~s}$ and $72^{\circ} \mathrm{C}$ for $45 \mathrm{~s}$, and one final extension at $72^{\circ} \mathrm{C}$ for $10 \mathrm{~min}$.

Table 2. Microsatellite loci used in the analysis of 120 Manihot esculenta plants grown in northern Mato Grosso State, Brazil.

\begin{tabular}{|c|c|c|}
\hline Locus & Sequence (5'-3') & Repeat motif \\
\hline SSRY21 & $\begin{array}{l}\text { F: CCTGCCACAATATTGAAATGG } \\
\text { R: CAACAATTGGACTAAGCAGCA }\end{array}$ & $(\mathrm{GA})_{26}$ \\
\hline SSRY28 & $\begin{array}{l}\text { F: TTGACATGAGTGATATTTTCTTGAG } \\
\text { R: GCTGCGTGCAAAACTAAAAT }\end{array}$ & $(\mathrm{CT})_{26}(\mathrm{AT})_{3} \mathrm{AC}(\mathrm{AT})_{2}$ \\
\hline SSRY27 & $\begin{array}{l}\text { F: CCATGATTGTTTAAGTGGCG } \\
\text { R: CCATTGGAGAACTTGGCAAC }\end{array}$ & $(\mathrm{CA})_{14}$ \\
\hline SSRY35 & $\begin{array}{l}\text { F: GCAGTAAAACCATTCCTCCAA } \\
\text { R: CTGATCAGCAGGATGCATGT }\end{array}$ & $(\mathrm{GT})_{3} \mathrm{GC}(\mathrm{GT})_{11}(\mathrm{GA})_{19}$ \\
\hline SSRY8 & $\begin{array}{l}\text { F: AGTGGTTTGAGAAGACTGGTGA } \\
\text { R: TTTCCAAAATGGAACTTCAAA }\end{array}$ & $(\mathrm{CA})_{14} \mathrm{CT}(\mathrm{CA})_{2}$ \\
\hline GAGG5 & $\begin{array}{l}\text { F: TAATGTCATCGTCGGCTCG } \\
\text { R: GCTGATAGCACAGAACACAG }\end{array}$ & NP \\
\hline GA12 & $\begin{array}{l}\text { F: GATTCCTCTAGCAGTTAAGC } \\
\text { R: CGATGATGCTCTTCGGAGGG }\end{array}$ & $\mathrm{NP}$ \\
\hline GA21 & $\begin{array}{l}\text { F: GGCTTCATCATGGAAAAACC } \\
\text { R: CAATGCTTTACGGAAGAGCC }\end{array}$ & NP \\
\hline GA131 & $\begin{array}{l}\text { F: TTCCAGAAAGACTTCCGTCCA } \\
\text { R: CTCAACTACTGCACTGCACTC }\end{array}$ & $\mathrm{NP}$ \\
\hline SSRY43 & $\begin{array}{l}\text { F: TCAGACGTTGATACCTCACTTCA } \\
\text { R: CCAGAGCATGGTCTTTCTGA }\end{array}$ & $(\mathrm{CT})_{25}$ \\
\hline SSRY126 & $\begin{array}{l}\text { F: AATGGATCATGTTCAATGTCTTC } \\
\text { R: TTGAAATACGGCTCAAGCTC }\end{array}$ & $(\mathrm{GT})_{2} \mathrm{~T}(\mathrm{GT})_{5}(\mathrm{GC})_{4}$ \\
\hline GA136 & $\begin{array}{l}\text { F: CGTTGATAAAGTGGAAAGAGCA } \\
\text { R: ACTCCACTCCCGATGCTCGC }\end{array}$ & $\mathrm{NP}$ \\
\hline GA140 & $\begin{array}{l}\text { F: TTCAAGGAAGCCTTCAGCTC } \\
\text { R: GAGCCACATCTACTCGACACC }\end{array}$ & NP \\
\hline SSRY40 & $\begin{array}{l}\text { F: TGCATCATGGTCCACTCACT } \\
\text { R: CATTCTTTTCGGCATTCCAT }\end{array}$ & $(\mathrm{GA})_{16}$ \\
\hline
\end{tabular}

$\mathrm{F}=$ forward locus; $\mathrm{R}=$ reverse locus; NP: Motif not published

The samples were sent to the Human Genome and Stem Cell Research Center, University of São Paulo, São Paulo (USP), where they were genotyped in ABI 3730 automatic sequencer (Applied Biosystems). Two fluorochromes (6-FAM [emitted blue fluorescence] and HEX [green]) were used in a duplex system. To assemble the duplex, the loci were chosen according to fluorescence and expected size of each locus. The reading in the automatic sequencer generated files containing the electropherograms, which were visualized and analyzed using GeneMarker software (v.2.6.3 Demo).

\section{Data analysis}

The following genetic diversity parameters were estimated using Power Marker software v.3.25: number of alleles $(\mathrm{Na})$, observed and expected heterozygosities $\left(H_{o}\right.$ and $H_{e}$ ), polymorphic information content (PIC) and fixation index ( $f$ ) (Liu and Muse, 2005).

Gene flow (Nm) was obtained by the PopGene 1.32 software (Yeh et al., 2000). Genetic differentiation of the populations $\left(\mathrm{F}_{\mathrm{ST}}\right)$ and the presence of rare $(\mathrm{Rr})$ and exclusive (Ex) alleles were performed and determined by the criterion proposed by Cruz et al. (2011) 
using the GenAlEx 6.5 software (Peakall and Smouse, 2012). Analysis of molecular variance (AMOVA) was performed as described by Excoffier et al. (1992) using the ARLEQUIN 3.0 software (Excoffier et al., 2005).

The genetic distance matrix, obtained in Power Marker v.3.25 software (Liu and Muse, 2005), was imported into MEGA 7.0 (Kumar et al., 2004) for constructing the dendrogram by the UPGMA method (Unweighted Pair-Group Method with Arithmetic Mean), whereas the cophenetic correlation coefficient (CCC) was obtained using the GENES software v. 6.0 (Cruz, 2013).

The number of genetic groups $(\mathrm{K})$ was indicated by Bayesian analysis, using the STRUCTURE software (Pritchard et al., 2000). Twenty iterations were performed for each $\mathrm{K}$ value $(\mathrm{K}=6)$, with 200,000 burn-in steps and 500,000 Markov Chain Monte Carlo (MCMC) simulations. The criteria proposed by Pritchard et al. (2010) and Evano et al. (2005) were adopted to define the most probable $\mathrm{K}$ in relation to those proposed

\section{RESULTS AND DISCUSSION}

The 14 microsatellite loci used in this study amplified a total of 97 alleles, at an average of 7.0 alleles per locus. Genetic diversity estimated by expected and observed heterozygosities was high for all loci. The respective parameters averaged 0.674 and 0.875 , respectively, indicating predominance of heterozygotes and, consequently, negative values for the fixation index. The average polymorphic information content was 0.621 (Table 3).

The polymorphic information content (PIC) is used to estimate the quality of the molecular marker to detection of polymorphism among individuals and it can be classified as satisfactory (PIC >0.5), medium $(0.25 \leq \mathrm{P} \leq 0.5)$ and low (PIC $<0.25)$ (Botstein et al., 1980). In this study, the PIC ranged from 0.292 (SSRY126) to 0.821 (SSRY27), averaging 0.621 ; therefore, ten loci were satisfactory and four were medium, indicating the efficiency of the microsatellite markers used. This agrees with other studies performed with the species, where the tested SSR's were highly polymorphic (Siqueira et al., 2009; Turyagyenda et al., 2012).

Table 3. Descriptive statistics by microsatellite loci of 120 Manihot esculenta plants cultivated in the municipalities of Alta Floresta, Terra Nova do Norte and Apiacás, northern Mato Grosso State, Brazil.

\begin{tabular}{|c|c|c|c|c|c|}
\hline Locus & $\mathrm{Na}$ & $\boldsymbol{H}_{e}$ & $\boldsymbol{H}_{o}$ & $F$ & $P I C$ \\
\hline SSRY21 & 05 & 0.560 & 0.983 & 0.754 & 0.462 \\
\hline SSRY28 & 10 & 0.833 & 0.924 & 0.105 & 0.812 \\
\hline SSRY27 & 11 & 0.839 & 0.957 & 0.137 & 0.821 \\
\hline SSRY35 & 06 & 0.757 & 0.916 & 0.205 & 0.713 \\
\hline SSRY8 & 08 & 0.582 & 1.000 & 0.716 & 0.494 \\
\hline GAGG5 & 03 & 0.508 & 0.925 & 0.818 & 0.391 \\
\hline GA12 & 06 & 0.669 & 0.784 & 0.169 & 0.622 \\
\hline GA21 & 05 & 0.668 & 0.832 & 0.241 & 0.608 \\
\hline GA131 & 07 & 0.784 & 1.000 & 0.271 & 0.751 \\
\hline SSRY43 & 08 & 0.765 & 0.822 & 0.070 & 0.729 \\
\hline SSRY126 & 06 & 0.331 & 0.333 & 0.004 & 0.293 \\
\hline GA136 & 11 & 0.745 & 0.819 & 0.094 & 0.706 \\
\hline GA140 & 07 & 0.738 & 0.958 & 0.294 & 0.704 \\
\hline SSRY40 & 04 & 0.661 & 1.000 & 0.511 & 0.593 \\
\hline Mean & 7.0 & 0.674 & 0.875 & 0.294 & 0.621 \\
\hline
\end{tabular}


The comparison of genetic diversity between the studied populations showed that the total number of alleles per population ranged between 55 and 72 . For the three populations, $H_{o}$ was higher than $H_{e}$, generating negative values for the fixation index $(f)$ (Table 4). The present results are similar to those reported by Turyagyenda et al. (2012) in a study involving the species in Uganda, but differ from those obtained by Silva et al. (2016) in an experiment with cassava harvested in Pará State, Brazil, where the fixation indices were positive, demonstrating the occurrence of inbreeding.

Table 4. Estimates of population genetic diversity of 120 Manihot esculenta individuals cultivated in the municipalities of Alta Floresta, Terra Nova do Norte and Apiacás, northern Mato Grosso State, Brazil.

\begin{tabular}{llllll}
\hline Population & $\boldsymbol{N a}$ & $\boldsymbol{H}_{\boldsymbol{e}}$ & $\boldsymbol{H}_{\boldsymbol{o}}$ & $\boldsymbol{f}$ & $\boldsymbol{P I C}$ \\
\hline AF & 55 & 0.638 & 0.935 & -0.455 & 0.566 \\
TN & 71 & 0.629 & 0.836 & -0.317 & 0.572 \\
AP & 72 & 0.647 & 0.855 & -0.308 & 0.592 \\
\hline
\end{tabular}

Number of alleles $(\mathrm{Na})$; expected heterozygosity $\left(H_{e}\right)$; observed heterozygosity $\left(H_{o}\right)$; fixation index $(f)$; and polymorphic information content (PIC).

A gene flow $(\mathrm{Nm})$ of 4.2 was found between the M. esculenta populations, indicating that the flow of cassava landraces among the farmers is intense and that local losses are compensated for by replacing materials of the existing landraces in the proximities of the rural areas of each farmer (Peroni, 2007).

The number of alleles whose frequency was lower than 0.05 in each population and which were thus considered rare (Cruz et al., 2001) was 28 (six in AF, 13 in TN and nine in AP). The populations with the highest number of rare alleles (TN and AP) should be highlighted in terms of conservation, because, as they show a low frequency, these alleles are susceptible to loss, which is due mainly to genetic drift (Allendorf et al., 2013). The presence of rare alleles in the populations is one of the requirements for the selection and conservation of genotypes, aiming at aiding breeding programs of the species.

Exclusive alleles are those whose occurrence is restricted to only one population in a given set of populations. In the current study, the three populations showed exclusive alleles, with AP aggregating the largest number, eight out of the ten. The presence of exclusive alleles may indicate priority regions for the conservation of the species, considering the maximization of genetic diversity (Montagna et al., 2012). Therefore, the population of Apiacás is noteworthy for conservation, as it contains rare alleles and the highest number of exclusive alleles.

AMOVA revealed greater genetic variation at the intrapopulation level (92\%) (Table 5), which was also found by Ortiz et al. (2016) in studies with cassava cultivars. The greater genetic variation within the populations was expected, since this is a species with vegetative propagation in which a continuous flow of 'maniva' (ground cassava leaves) prevails between regions as facilitated by farmers and consumers. Fukuda et al. (2002) also stressed that in species like cassava, in which cross-pollination and vegetative reproduction occur, the greatest genetic diversity is found within the populations.

The $120 \mathrm{M}$. esculenta individuals were divided by the UPGMA clustering method into two main groups, with distribution independent of the collection site (Figure 2). Group 
I consisted of 61 individuals, whereas group II contained 59 individuals. Both genetic groups included individuals from the three sampled populations.

Table 5. Analysis of Molecular Variance (AMOVA) of the three cultivated populations of Manihot esculenta analyzed with 14 microsatellite markers.

\begin{tabular}{|c|c|c|c|c|c|c|}
\hline Source of variation & DF & SS & $\mathrm{VC}$ & TV (\%) & $\mathbf{F}_{\mathrm{ST}}$ & $\mathbf{P}$ \\
\hline Interpopulational & 2 & 59.848 & 0.333 & 8 & 0.082 & $<0.001$ \\
\hline Intrapopulational & 233 & 867.991 & 3.725 & 92 & & \\
\hline Total & 235 & 927.839 & 4.058 & 100 & & \\
\hline
\end{tabular}

Degrees of freedom (DF); Sum of squares (SS); Variance component (VC), Total variance (TV), Fixation index between the populations $\left(\mathrm{F}_{\mathrm{ST}}\right)$; and Significance probability $(\mathrm{P})$.

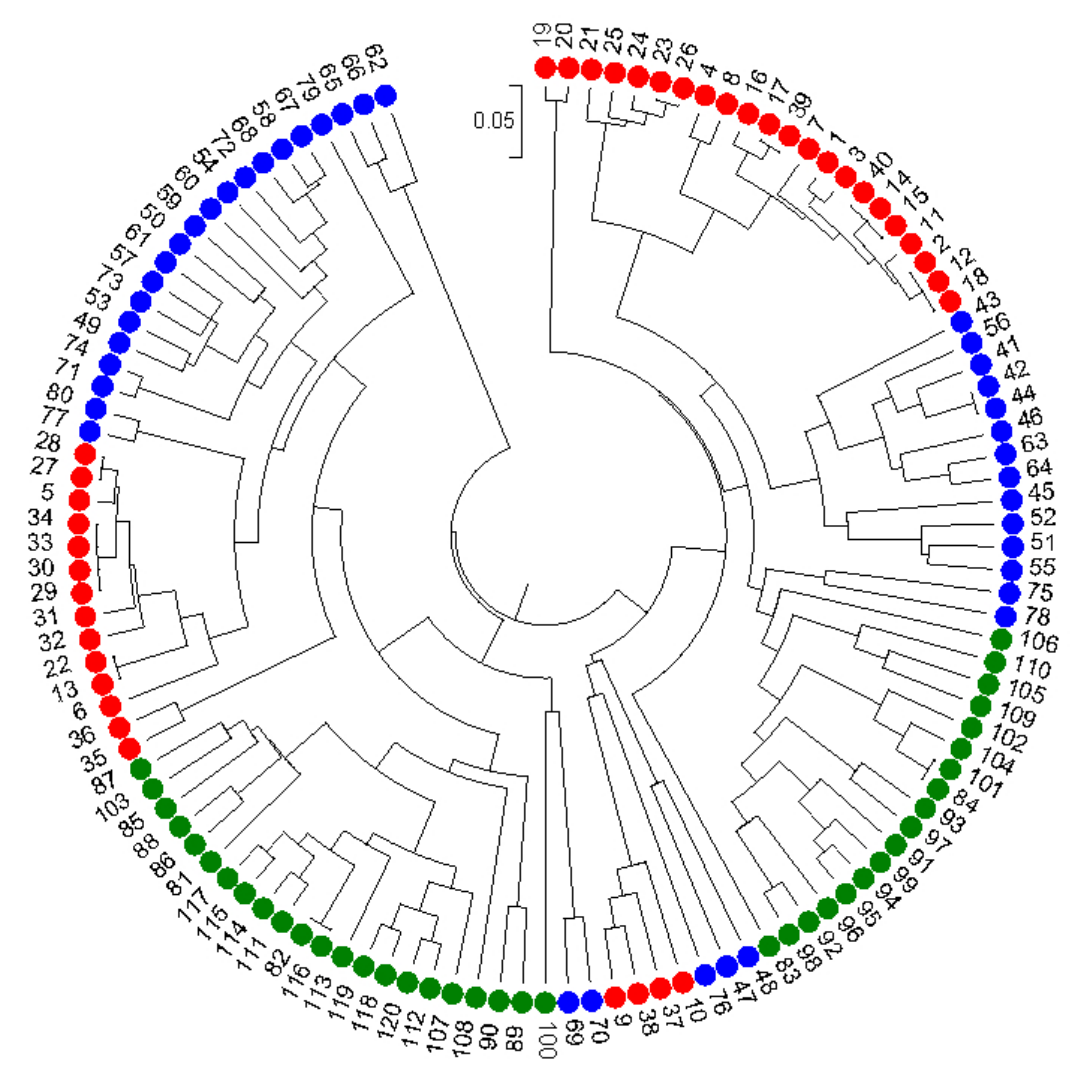

Figure 2. Clustering of the 120 individuals of Manihot esculenta obtained by the UPGMA method, based on Nei's (1983) genetic distance. Alta Floresta (1-40) (red); Terra Nova do Norte (41-80) (blue); Apiacás (81-120) (green). $\mathrm{CCC}=0.82 ;$ Distortion $=3.78 \%$; Stress $=19.43 \%$.

Bayesian analysis confirms the result obtained by the UPGMA method, with two genetic groups formed $(\mathrm{K}=2)$. The only difference is that, by this method, AP106, TN66, TN65, and TN62 were allocated to group I (Figure 3). The interchange of landraces among farmers can explain the lack of genetic and geographic structuring in the samples of the 
studied populations. Cross-pollination, a typical characteristic of allogamous plants such as M. esculenta, might also have contributed to this result, as described by Ortiz et al. (2016), Martins and Oliveira (2009) and Kizito et al. (2007).
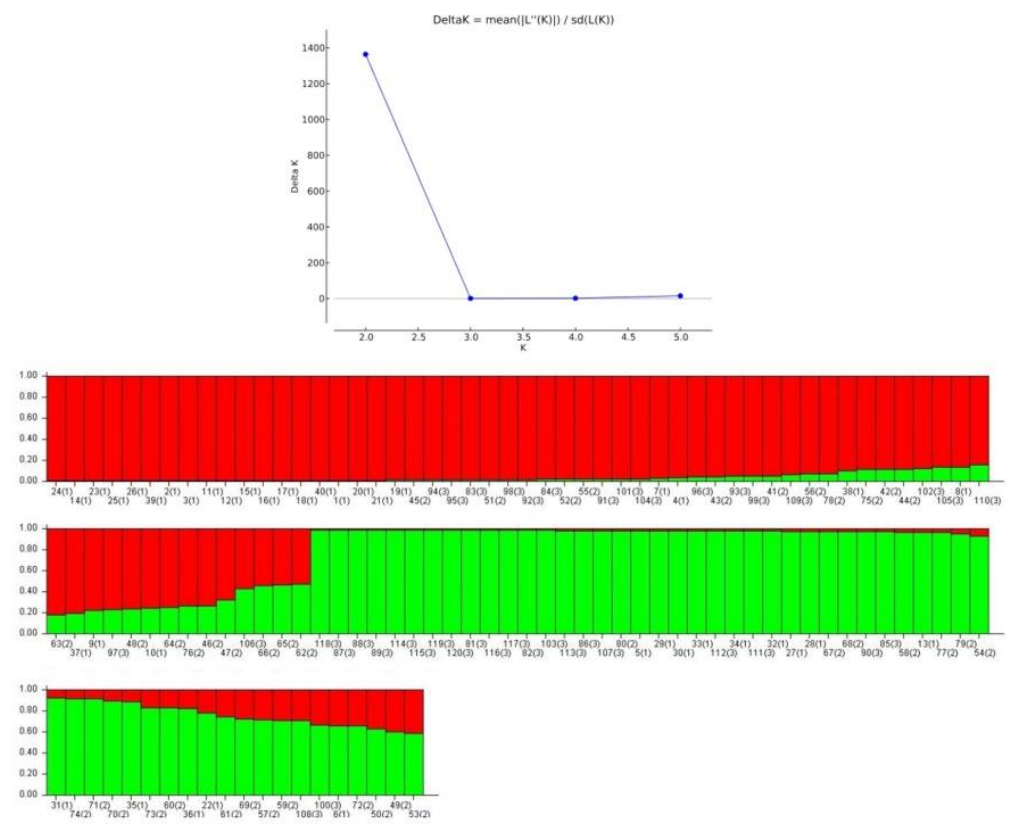

Figure 3. Representation of the 120 plants of three Manihot esculenta populations based on 14 microsatellite markers, assuming $\mathrm{K}=2$ (groups). The groups are represented by vertical bars in the colors red (group I) and green (group 2). Alta Floresta (1); Terra Nova do Norte (2); Apiacás (3).

\section{CONCLUSIONS}

There is considerable genetic diversity in the M. esculenta populations cultivated in northern Mato Grosso State. This contemporary scenario found on family farms, where landraces are selected based on phenotypic traits, has ensured the genetic variability of cassava in plantings in Mato Grosso State. The gene flow found in this study is a result of the introduction and exchange of genetic material (landraces) performed by farmers, who act on their farms as maintainers of local diversity.

Manihot esculenta plantings in northern Mato Grosso State ensure on-farm conservation of genetic variability of the species and constitute a source of genetic resources such as resistance and adaptation genes that can be exploited and utilized in breeding programs.

\section{ACKNOWLEDGMENTS}

The present research was supported by the Amazon Fund/BNDES and the Coordination for the Improvement of Higher Education Personnel - Brazil (CAPES) - Grant code 001 . 


\title{
CONFLICTS OF INTEREST
}

\author{
The authors declare no conflict of interest.
}

\section{REFERENCES}

Allem AC (2002). The origins and taxonomy of cassava. In: Hillocks RJ, Thresh JM, Bellotti AC. Cassava: Biology, Production and Utilization. CAB International. 2002. 16p.

Allendorf FW, Luikart G and Aitken SN (2013). Conservation and Genetics of Populations. Second Edition. Wiley Blackwell.

Alvares CA, Stape JL, Sentelhas PC, Gonçalves JLM, et al. (2013). Koppen's climate classification map for Brazil. Meteorol Z. 22(6): 711-728.

Beovides Y, Fregene M, Gutiérrez JP, Milián MD, et al. (2015). Molecular diversity of Cuban cassava (Manihot esculenta Crantz) cultivars assessed by simple sequences repeats (SSR). Biotechnol. Agron. Soc. Environ. 19(4): 364-377.

CONAB (2019). Companhia Nacional de Abastecimento. Histórico Mensal Mandioca. 2019. Available at [https://www.conab.gov.br/info-agro/analises-do-mercado-agropecuario-e-extrativista/analises-domercado/historico-mensal-de-mandioca]. Accessed 10 June 2019.

Cruz CD (2013). GENES - a software package for analysis in experimental statistics and quantitative genetics. Acta Sci. Agron. 35(3): 271-276.

Botstein D, White RL, Skolnick M and Davis RW (1980). Construction of a genetic linkage map in man using restriction fragment length polymorphisms. Am. J. Hum. Genet. 32(3): 314.

Chavarriaga-Aguirre P, Maya MM, Bonierbale MW, Kresovich S, et al. (1998). Microssatellites in Cassava (Manihot esculenta Crantz): discovery, inheritance and variability. Theor. Appl. Genet. 97: 493-501.

CONAB. Companhia Nacional de Abastecimento

Cruz CD, Ferreira FM and Pessoni LA (2011). Biometria Aplicada ao estudo da diversidade genética. Visconde do Rio Branco, MG: Suprema.

Doyle JJ and Doyle JL (1987). A Rapid DNA isolation procedure for small quantities of fresh leaf tissue. Phytochem. Bull. 19(1): 11-15.

Elias M, Muhlen GS, Mckey D and Roa AC (2004). Genetic diversity of traditional of cassava (Manihot esculenta Crantz): an analysis using microsatellites. Economic Botany. 58(2): 242-256.

Evano G, Regnaut S and Goudet J (2005). Detecting the number of clusters of individuals using the software STRUCTURE: a simulation study. Mol. Ecol. 14: 2611-2620.

Excoffier L, Smouse PE and Quattro JM (1992). Analysis of molecular variance inferred from metric distances among DNA haplotypes: application to human mitochondrial DNA restriction data. Genetics. 131: 479-491.

Excoffier L, Laval G and Schneider S (2005). Arlequin (version 3.0): An integrated software package for population genetics data analysis. Evol. Bioinform. Online. 1: 47-50

Faraldo MIF, Silva RM, Ando A and Martins PS (2000). Variabilidade genética de etnovariedades de mandioca em regiões geográficas do Brasil. Sci. Agric. 57(3): 499-505.

Ferreira ME and Grattapaglia D (1998). Introdução ao uso de marcadores moleculares em análise genética. Brasília: Embrapa-Cenargen, 220p. (Documento 20).

Fukuda WMG, Silva SO and Iglesias C (2002). Cassava Breeding. Crop Breed Appl. Biot. 2(4): 617-638.

Fukuda WMG, Cavalcanti J, Fukuda C and Costa IRS (2005). Variabilidade genética e melhoramento da mandioca (Manihot esculenta Crantz). Recursos Genéticos e Melhoramento de Plantas para o Nordeste Brasileiro. Available at [http://www.cpatsa.embrapa.br/catalogo/livrorg/mandioca.pdf]. Accessed May 30, 2019.

Flora do Brasil. Manihot esculenta Crantz. Jardim Botânico do Rio de Janeiro. Available at [http://www.floradobrasil.jbrj.gov.br/reflora/floradobrasil/FB17600]. Accessed 10 June 2019.

Gonçalves TM, Vidigal Filho PS, Vidigal MCG, Ferreira RCU, et al. (2017). Genetic diversity and populations structure of traditional sweet cassava accessions from Southern of Minas Gerais State, Brazil, using microsatellite markers. Afr. J. Biotechnol. 16(8): 346-358.

Guimarães CT, Magalhães JV, Lanza MA and Schuster I (2009). Marcadores moleculares e suas aplicações no melhoramento genético. Informe Agropecuário. 30(253): 24-33.

IBGE. Instituto Brasileiro de Geografia e Estatística. Produção Agrícola - Lavoura Temporária. Available at [https://cidades.ibge.gov.br/brasil/mt/pesquisa/14/10193]. Accessed 10 June 2019.

Kizito EB, Chiwona-Karltun L, Egwang T, Fregene M, et al. (2007). Genetic diversity and variety composition of cassava on small-scale farms in Uganda: an interdisciplinary study using genetic markers and farmer interviews. Genetics. 130(3): 301-318.

Kumar, S, Tamura K and Nei M (2004). MEGA3: Integrated software for Molecular Evolutionary Genetics Analysis and sequence alignment. Brief Bioinform. 5(2): 150-163. 
Liu K and Muse SV (2005). PowerMarker: Integrated analysis environment for genetic marker data. Bioinformatics. 21(2128): 21-29.

Marchetti FF, Massaro Junior LR, Amorozo MCM and Butturi-Gomes D (2013). Maintenance of Manioc Diversity by Traditional Farmers in the State of Mato Grosso, Brazil: A 20-Year Comparison. Econ. Bot. 67(4): 313-323.

Martins OS and Oliveira GCX (2009). Dinâmica evolutiva em roças de caboclos amazônicos. In: Vieira ICG, Silva JMC, Oren DC, D'Incao MA. Diversidade biológica e cultural da Amazônia. 2.ed. Belém: Museu Paraense Emílio Goeldi. p. 373-391.

Mba REC, Stephenson P, Edwards K, Melzer S, et al. (2001). Simple sequence repeat (SSR) markers survey of the cassava (Manihot esculenta Crantz) genome: towards an SSR-based molecular genetic map of cassava. Theor. Appl. Genet. 102: 21-31.

Montagna T, Ferreira DK, Steiner F, Fernandes CD, et al. (2012). A Importância das Unidades de Conservação na Manutenção da Diversidade Genética de Xaxim (Dicksonia sellowiana) no Estado de Santa Catarina. Biodiversidade Brasileira. 2(2): 26-32.

Moura EF, Farias Neto JT, Sampaio JE, Da Silva DT, et al. (2013). Identification of duplicates of cassava accessions sampled on the North Region of Brazil using microsatellite markers. Acta Am. 43(4): 461-468.

Moura EF, Sousa NR, Moura MF, Dias MC, et al. (2016). Molecular characterization of accessions of a rare genetic resource: sugary cassava (Manihot esculenta Crantz) from Brazilian Amazon. Genet. Resour. Crop Evol. 63: 583593.

Nei M, Tajima F and Tateno Y (1983). Accuracy of estimated phylogenetic trees from molecular data. J. Mol. Evol. 19: 153-170.

Oler JRL and Amorozo MCM (2017). Etnobotânica e conservação on farm de mandioca (Manihot esculenta Crantz) na agricultura de pequena escala no Estado de Mato Grosso, Brasil. Interações. 18(4): 137-153.

Ortiz AHT, Rocha VPC, Moiana LD, Gonçalves-Vidigal MC, et al. (2016). Population structure and genetic diversity in sweet cassava cultivars from Paraná, Brazil. Plant Mol. Biol. Rep. 34(6): 1153-1166.

Peakall R and Smouse PE (2012). GenAlEx 6.5: genetic analysis in Excel. Population genetic software for teaching and research-an update. Bioinformatics. 28(19): 2537-2539.

Pereira MG, Ramos HCC, Pereira TNS and Batista FRC (2016). Marcadores Moleculares no Pré-Melhoramento. In: Borém A, Caixeta E. Marcadores Moleculares. Viçosa: UFV. p. 95-128.

Peroni N (2007). Manejo e domesticação de mandioca por caiçaras da Mata Atlântica e ribeirinhos da Amazônia. In: Boef WS, Thijssen MH, Ogliari JB, Sthapit BR. Biodiversidade e agricultores: fortalecendo o manejo comunitário. Porto Alegre, RS: L\&PM. p.234-242.

Pritchard JK, Stephens M and Donnelly P (2000). Inference of Population Structure Using Multilocus Genotype Data. Genet. 155(2): 945-959.

Pritchard JK, Wen X and Falush D (2010). Documentation for structure software: Version 2.3. p.1-38.

Ribeiro MNO, Carvalho SP, Santos JB and Antonio RP (2011). Genetic variability among cassava accessions based on SSR markers. Crop Breed Appl Biot. 11: 263-269.

Schuelke M (2000). Na economic method for the fluorescent labeling of PCR fragments. Nat. Biotechnol. 18: 233-234.

Santonieri L and Bustamante PG (2016). Conservação ex situ e on farm de recursos genéticos: desafios para promover sinergias e complementaridades. Bol. Mus. Para. Emílio Goeldi. 11(3): 677-690.

Silva RS, Moura EF, Farias Neto JT, Sousa NR, et al. (2016). Genetic divergence among accessions of cassava (Manihot esculenta Crantz) sampled in the Tapajós region, State of Pará, using agronomic characters and microsatellite markers. Semina: Ciênc. Agrár. 37(5): 2989-3004.

Siqueira MVBM, Pinheiro TT, Borges A, Valle TL, et al. (2010). Microsatellite Polymorphisms in Cassava Landraces from the Cerrado Biome, Mato Grosso do Sul, Brazil. Biochem Genet. 48: 879-895.

Siqueira MVBM, Queiroz-Silva JR, Bressan EA, Borges A, et al. (2009). Genetic characterization of cassava (Manihot esculenta) landraces in Brazil assessed with simple sequence repeats. Genet. Mol. Biol. 32(1): 104-110.

Souza DCL. (2015). Técnicas moleculares para caracterização e conservação de plantas medicinais e aromáticas: uma revisão. Rev. Bras. Plantas Med. 17(3): 495-503.

Tiago AV, Rossi AAB, Tiago PV, Carpejani AA, et al. (2016). Genetic diversity in cassava landraces grown on farms in Alta Floresta-MT, Brazil. Genet. Mol. Biol. 15(3): 1-10.

Tumuhimbise R, Melis R, Shanahan P and Kawuki R (2014). Genotype x environment interaction effects on early fresh storage root yield and related traits in cassava. Crop J. 2: 329-337.

Turyagyenda LF, Kizito EB, Ferguson ME, Baguma Y, et al. (2012). Genetic diversity among farmer-preferred cassava landraces in Uganda. Afr. Crop Sci. J. 20(1): 15-30.

Yeh FC, Yang RC, Boyle TBJ, Ye Z, et al. (2000). POPGENE version 1.32: Microsoft Window-based freeware for population genetic analysis. Edmonton: University of Alberta. 